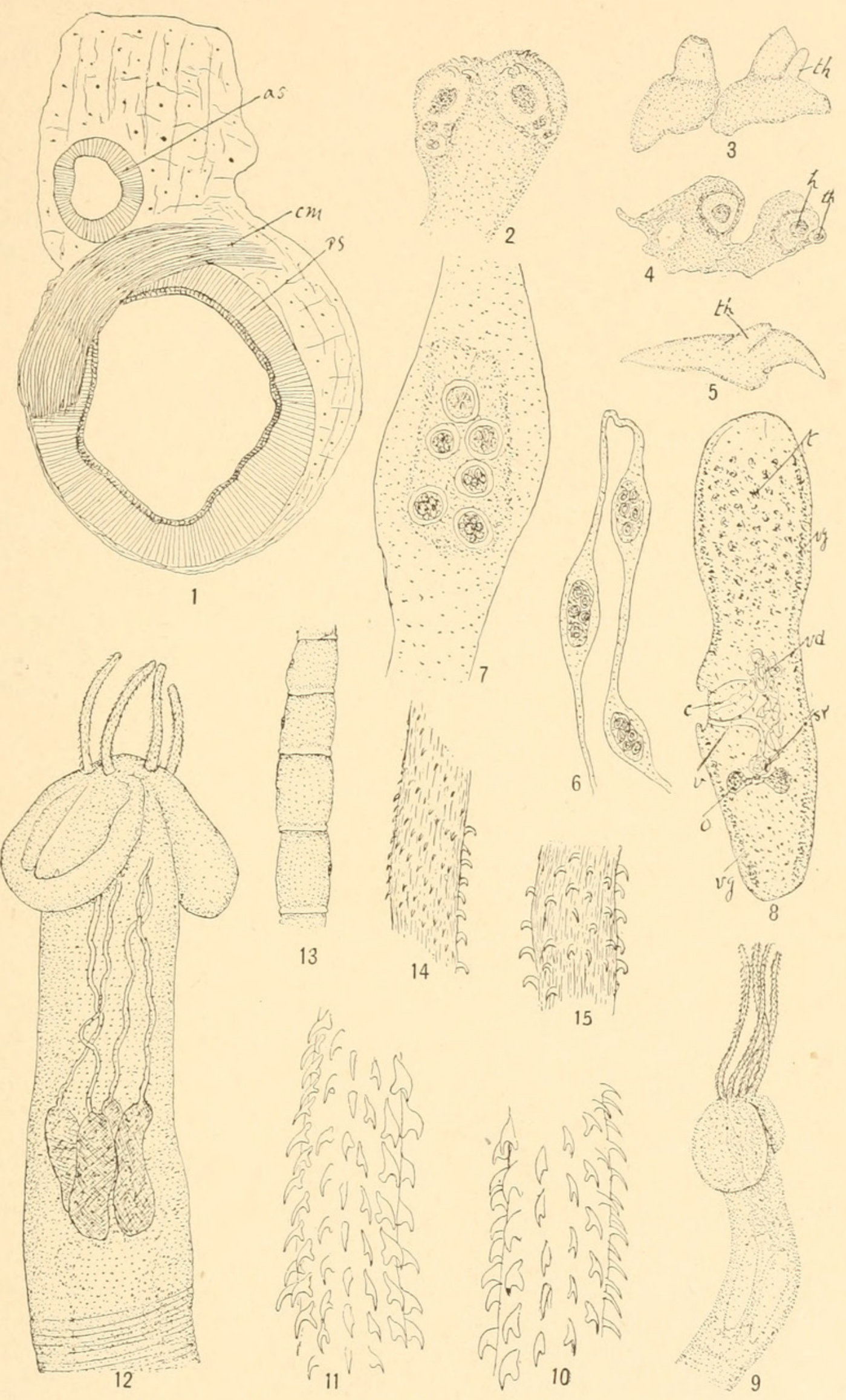

PARASITIC WORMS (Orygmatobothrium and Onchobothrium) FROM STING RAY, (Calliobothrium) FROM DOGFISH, AND (Rhynchobothrium) FROM STING RAY AND COWNOSED RAY. 



\title{
PRELIMINARY DIAGNOSES OF NEW MAMMALS OF THE GENERA LYNX, UROCYON, SPILOGALE, AND MEPHITIS, FROM THE MEXICAN BOUNDARY LINE.
}

\author{
By Edgar A. Mearns, M. D., \\ Assistant Surgeon, United States Army.
}

THIs is the fifth of a series of papers giving preliminary descriptions of the new mammals collected on the recent survey of the boundary between Mexico and the United States. ${ }^{1}$ Detailed descriptions, with illustrations of the new forms, and comparisons with their allies will appear later in the report on the collections made by the International Boundary Commission.

LYNX RUFUS EREMICUS, new subspecies.

DESERT LYNX.

Type.-No. 60676, U.S.N.M. (Collection International Boundary Commission.) Skin and skull. Adult male, from New River, 6 miles northwest of Laguna Station, on the Colorado Desert, in San Diego County, California. Collected by Dr. Mearns, May 5, 1894. Original number, 3506 .

Description of type.-In winter pelage. Above pale yellowish brown, mixed with gray and black, obscurely spotted and striped with brown and blackish from the nape to the root of the tail. Legs ochraceousbuff, mixed with grayish. Under side of body and of tail, white. Chest, belly, and inner side of limbs, spotted or banded with black. The sides and outside of limbs are spotted with yellowish brown. Tail, reddish brown above, white below, with a subterminal spot of black. Ears, pale gray, with a blackish spot at base, and black on apex and terminal pencil; the usual gray spot, in this form, extends as a band clear across the convexity of the ear; inner surface of ear, white. Under side of hınd foot with a narrow longitudinal line of black, bordered by sooty. Crown and cheeks with obsolete rusty stripes. Sides of

${ }^{1}$ Proc. U. S. Nat. Mus., XVIT, 1894, pp. 129-130; XVIII, 1895, pp. 443-447, 551-565; XIX, 1896, pp. 137-140.

[Advance sheets of this paper were published January 12, 1897.] 
upper lip with four lines of small black spots; edge of lip, black posteriorly. Tail, with about seven transverse dorsal bars of black, which become obsolete toward the base. Length, $925 \mathrm{~mm}$; tail vertebræ, 170 (to end of hairs, 195); ear from crown, 75; ear from anterior base, 82 ; length of ear pencil, 23 ; distance between eyes, 33 ; longest whisker, 90 ; from tip of nose to angle of mouth, 50 ; to cye, 48 ; to center of pupil, 59 ; to ear, 117; to tip of ear, 202; to occiput, 140 ; to end of outstretched hind limb, 1,190; fore limb, measured from olecranon process to end of longest elaw, 287; length of fore foot, 133; longest claw of manus (chord), 18; hind limb from knee-joint to end of claws, 325 ; length of hind foot, 185; longest claw of pes, 18.

Geographical range.-This subspecies inhabits the eastern and western clesert tracts, on the Mexican line. In the "Eastern Desert Tract" its ears are shorter, and its color appears to be redder in summer.

\section{LYNX RUFUS CALIFORNICUS, new subspecies.}

\section{CALIFORNIAN LYNX.}

Type.-No. $\frac{1588}{37163}$, U.S.N.M. Skin and skull. Adult female, from San Diego, California; collected February 2, 1856, by Doctor J. F. Hammond, who recorded the following measurements: Length of head, $5 \frac{3}{4}$ inches; body, 28; tail, 7 .

Description of type.-In winter coat. Similar to Lynx rufus texensis (Allen), but browner, less spotted, and with larger ears. Coloration dark. Above reddish brown, considerably mixed with gray and black; decidedly dusky in the median line, with two parallel, interrupted, black lines extending from the shoulders to the root of the tail. Onter surface of limbs, and sides, ochraceous-buff, mixed with gray and spotted with yellowish brown. Inner surface of limbs, under surface of head and body, and under side and tip of tail, white. Chest with a broad, rusty-grayish collar which is conspicuously spotted with black. Under side of body and inner surface of limbs banded or spotted with black. Under side of hind foot with the usual median black stripe. Ears much larger than those of Lynx rufus, but marked much the same; white inside, edged with grayish white, and black on the convex surface, the black contributing a liberal terminal pencil, and inclosing a small triangular patch of gray. The upper lip has a large, black marginal spot on each side.

Geographical range-This form of lynx occupies the "Pacific Coast Tract" of California and Lower California.

${ }^{1}$ See Proc. U. S. Nat. Mus., XIX, 1896, p. 137, for definition of geographic differentiation areas on the Mexican boundary line. 
UROCYON CINEREOARGENTEUS TEXENSIS, new subspecies.

TEXAN GRAY FOX.

Type.-No. $\frac{130}{1116}$, U.S.N.M. Skin and skull. From San Pedro, near Eagle Pass, Texas; collected in 1851 by Arthur Schott, a naturalist of the old Mexican boundary survey, under Lieut. Col. W. H. Emory.

Description of type.-Similiar to $U$. cinereoargenteus, but paler, with larger ears, and a longer tail. The markings of the limbs, sides of neck, and base of ears, which are chestnut or cinnamon-rufous in the typical form, are ochraceous. Height of ear above crown, $80 \mathrm{~mm}$.; length of hind foot, 128 ; length of caudal vertebræ, 350 .

Another specimen taken by the same collector on the lower Rio Grande (No. $\frac{201}{1175}$, U.S.N.M.), agrees with the above, except in having a few gray-and-black hairs on the limbs, and a little darker coloration. It is probable that these two specimens represent different seasonal pelages, as that of the last-mentioned example is coarser and harsher. Other specimens from northern Mexico and extreme southwestern Texas approach Urocyon cinereoargenteus scottii.

This subspecies inhabits the Texan region, and finds its nearest analogue in the form inhabiting the Pacific coast of southern and Lower California, described below, the two being separated on the Mexican border by the range of $U$. c. scottii of the interior region.

\section{UROCYON CINEREOARGENTEUS CALIFORNICUS, new subspecies.}

CALIFORNIAN GRAY FOX.

Type.-No. 62873, U.S.N.M. Skin and skull. Adult male, from the San Jacinto Mountains, altitude 8,000 feet, Riverside County, California; collected by Mr. A. W. Anthony, July 6, 1895. Original number, 41 .

Description of type.-Similar to Urocyon cinereoargenteus, but smaller and paler, with larger ears and relatively longer tail. Length, $890 \mathrm{~mm}$; caudal vertebræ, 330; ear from crown, 85; length of hind foot, 120. Compared with the gray fox of New York, the skull is smaller, relatively broader, with a higher brain case, and with the temporal crests much more widely separated. The coronoid process of the mandible is more nearly vertical.

Remarks.-This is a dark coast form, differing widely from that of the interior region, which I have named ${ }^{1} U$. c. scottii. It is about as darkly colored as the Texas gray fox, described above, but differs from it considerably in the shades of coloring, and also somewhat in proportions. It differs from $U$. c. texensis chiefly in having larger ears, and grayer, less fulvous coloring.

The gray foxes of northern California are almost like those from New 


\section{$2 \mathrm{BHL}$ Biodiversity Heritage Library}

Mearns, Edgar Alexander. 1897. "Preliminary diagnoses of new mammals of the genera Lynx, Urocyon, Spilegale, and Mephitis, from the Mexican boundary line." Proceedings of the United States National Museum 20(1126), 457-461. https://doi.org/10.5479/si.00963801.1126.457.

View This Item Online: $\underline{\text { https://www.biodiversitylibrary.org/item/53812 }}$

DOI: https://doi.org/10.5479/si.00963801.1126.457

Permalink: https://www.biodiversitylibrary.org/partpdf/53241

\section{Holding Institution}

Smithsonian Libraries

\section{Sponsored by}

Smithsonian

\section{Copyright \& Reuse}

Copyright Status: Public domain. The BHL considers that this work is no longer under copyright protection.

This document was created from content at the Biodiversity Heritage Library, the world's largest open access digital library for biodiversity literature and archives. Visit BHL at https://www.biodiversitylibrary.org. 